\title{
MENINGKATKAN HASIL BELAJAR IPS MELALUI PENERAPAN MODEL PEMBELAJARAN KOOPERATIF TIPE NUMBERED HEADS TOGETHER (NHT) DI KELAS VI SDN 1 KOROHA
}

\author{
Ratna D. Maponga ${ }^{1)}$, La Anse ${ }^{2)}$. \\ ${ }^{1)}$ SDN 1 Koroha, Kolaka Utara, Indonesia \\ ${ }^{2)}$ Jurusan PGSD, Universitas Halu Oleo, Kendari, Indonesia \\ email: ratnadmapongaa.pji@gmail.com
}

\begin{abstract}
Abstrak: Penelitian ini bertujuan untuk meningkatkan hasil belajar IPS pada materi sistem administrasi wilayah Indonesia siswa melalui penerapan model pembelajaran kooperatif Tipe Numbered Head Together (NHT) di kelas VI SDN 1 Koroha Kabupaten Kolaka Utara. Prosedur penelitian yaitu; (a) perencanaan (planning), (b) pelaksanaan tindakan (action), (c) observasi dan evaluasi (observation and evaluation), dan (d) refleksi (reflection). Jenis data yaitu data kualitatif dan data kuantitatif. Data kualitatif diperoleh melalui lembar observasi sedangkan data kualitatif melalui tes hasil belajar. Hasil penelitian yaitu hasil tes siklus I, Dari segi proses, aktivitas guru dan siswa telah mencapai indikator keberhasilan yaitu $80 \%$. Aktivitas guru pada siklus I pertemuan pertama sebesar $62,5 \%$ dan pada pertemuan kedua sebesar $75 \%$, meningkat pada siklus II pertemuan pertama menjadi $87,5 \%$ dan pertemuan kedua $100 \%$. Aktivitas siswa pada siklus I pertemuan pertama sebesar $62,5 \%$ dan pada pertemuan kedua sebesar $75 \%$, meningkat pada siklus II pertemuan pertama menjadi $87,5 \%$ dan pertemuan kedua $100 \%$. Dari segi hasil yaitu hasil belajar siswa, rata-rata hasil belajar siswa pada siklus I sebesar 73 dengan ketuntasan klasikal sebesar $72 \%$ meningkat pada siklus II menjadi 81,2 dengan persentase ketuntasan klasikal sebesar $92 \%$.
\end{abstract}

Kata kunci: Model pembelajaran; NHT; Hasil Belajar.

\section{IMPROVING STUDENT LEARNING OUTCOMES IN IPS THROUGH THE IMPLEMENTATION OF NUMBERED HEADS TOGETHER (NHT) COOPERATIVE LEARNING MODELS IN CLASS VI SDN 1 KOROHA}

\begin{abstract}
This study aims to improve social studies learning outcomes in the material of the Indonesian regional administration system through the application of the Numbered Head Together (NHT) cooperative learning model in class VI SDN 1 Koroha, North Kolaka Regency. Research procedures, namely; (a) planning, (b) action, (c) observation and evaluation, and (d) reflection. Types of data are qualitative data and quantitative data. Qualitative data were obtained through observation sheets, while qualitative data were obtained through learning outcomes tests. The results of the study were the results of the cycle I test. In terms of the process, the activities of teachers and students had reached the success indicator, namely $80 \%$. Teacher activity in the first cycle of the first meeting was $62.5 \%$ and at the second meeting it was $75 \%$, increasing in the second cycle the first meeting was $87.5 \%$ and the second meeting was $100 \%$. Student activity in the first cycle of the first meeting was $62.5 \%$ and at the second meeting it was $75 \%$, increasing in the second cycle the first meeting was $87.5 \%$ and the second meeting was $100 \%$. In terms of results, namely student learning outcomes, the average student learning outcomes in the first cycle of 73 with $72 \%$ classical completeness increased in the second cycle to 81.2 with a classical completeness percentage of $92 \%$.
\end{abstract}

Key words: learning model; NHT; Learning outcomes. 


\section{Pendahuluan}

Pendidikan merupakan suatu usaha mengubah pengetahuan, pengalaman, kecakapan serta keterampilan dari generasi tua kepada generasi muda agar bermanfaat hidupnya, baik jasmani maupun rohani. Melalui kegiatan mengajar, guru mendidik siswa dengan melatih keterampilan dan membantu anak agar mampu mengembangkan potensi yang ada agar lebih berkembang serta belajar terus menerus. Guru memiliki peranan penting dalam hal menumbuhkan dan mengembangkan minat belajar siswa. Salah satu tugas guru adalah menciptakan suasana pembelajaran yang dapat memotivasi siswa untuk senantiasa belajar dengan baik dan bersemangat. Suasana pembelajaran yang demikian akan berdampak positif dalam pencapaian hasil belajar yang optimal.

Realitas yang terjadi bahwa kegaiatan pembelajaran berlangsung secara menoton, penyampaian materi yang konvensional, sehingga siswa merasa jenuh dan bosan ketika mengikuti proses pembelajaran dan menjadikan siswa malas belajar. Kondisi tersebut di atas berdampak pada hasil belajar siswa. Berdasarkan dokumen guru kelas VI SD Negeri 1 Koroha Kabupaten Kolaka Utara tahun ajaran 2015/2016 dari 20 siswa terdapat 12 siswa atau $60 \%$ berada di bawah KKM yaitu 70 .

Menyikapi kondisi dan realitas tersebut di atas perlu dilakukan upaya untuk memperbaiki hasil belajar siswa pada SD Negeri 1 Koroha Kabupaten Kolaka Utara dengan menerapkan strategi atau model pembelajaran yang inovatif dan progresif. Salah satu model pembelajaran yang memungkinkan untuk meningkatkan hasil belajar IPS siswa kelas VI SD Negeri 1 Koroha Kabupaten Kolaka Utara adalah melalui model pembelajaran kooperatif tipe Numbered Heads Together (NHT).

Penerapan model pembelajaran kooperatif tipe NHT merupakan kegiatan pembelajaran yang menciptakan suasana siswa merasa ambil bagian dan berperan aktif dalam proses kegiatan pembelajaran, lebih rileks di samping menumbuhkan tanggung jawab, kerjasama, persaingan sehat dan keterlibatan belajar,. Hal ini didukung pendapat Menurut Lie (Nursyamsi, dkk. 2016) Numbered Heads Together (NHT) atau kepala bernomor adalah suatu tipe dari pengajaran kooperatif pendekatan struktural yang memberikan kesempatan kepada siswa untuk saling membagikan ide-ide dan mempertimbangkan jawaban yang paling tepat.. Salah satu yang ditempuh guru adalah mengembangkan pola pembelajaran menekankan kerjasama antar siswa dalam membentuk individu siswa menjadi manusia yang demokratis. Model pembelajaran kooperatif Tipe NHT ini, pada hakikatnya dirancang untuk memberikan kesempatan pada siswa dapat belajar melalui kegiatan bermain, berlomba dan bekerjasama dalam tim. Keberhasilan dari penerapan pembelajaran kooperatif tipe NHT ini bergantung kepada peran dan kesiapan guru di dalamnya. Peran guru tersebut sangat tergantung dari kegiatan pembelajaran yang digunakan, juga materi yang sedang diajarkannya.

Atas dasar inilah penulis termotivasi untuk melakukan penelitian tindakan kelas dengan judul Meningkatkan Hasil Belajar Siswa pada Mata Pelajaran IPS Materi Sistem Administrasi Wilayah Indonesia Melalui Penerapan Model Pembelajaran Kooperatif Tipe Numbered Heads Together (NHT) di Kelas VI SD Negeri 1 Koroha Kabupaten Kolaka Utara.

Hasil penelitian yang dilakukan oleh Istiana (2012) dengan judul penelitian Upaya Meningkatkan Hasil Belajar IPS Melalui Model Pembelajaran Kooperatif Tipe Numbered Head Together (NHT) pada Siswa Kelas IV SD Negeri 2 Lawoila Kabupaten Konawe Selatan. Disimpulkan bahwa hasil belajar siswa pada materi kenampakan alam berdasarkan keragaman budaya dapat ditingkatkan melalui model pembelajaran kooperatif tipe NHT pada SDN 2 Lawoila Kabupaten Konawe Selatan.

Hasil penelitian yang dilakukan oleh Salim (2013) dengan judul penelitian Meningkatkan Hasil Belajar IPS Melalui Model Pembelajaran Kooperatif Tipe Numbered Head Together (NHT) pada Siswa Kelas IV SD Negeri 13 Poasia. Disimpulkan bahwa 
dengan menggunakan model kooperatif tipe NHT dalam mengajarkan materi mengenal permasalahan sosial di daerah pada Siswa Kelas IV SDN 13 Poasia hasil belajar IPS dapat meningkat.

Model Pembelajaran Kooperatif Tipe Numbered Head Together dirancang secara matang dan dilaksanakan secara tepat diharapkan dapat mendorong siswa lebih dapat meningkatkan persiapan dalam menerima pelajaran. Peningkatan motivasi belajar siswa juga diharapkan membawa dampak positif yaitu peningkatan hasil belajar siswa.

Masalah dalam penelitian adalah apakah hasil belajar IPS pada materi sistem administrasi wilayah Indonesia siswa dapat ditingkatkan melalui penerapan model pembelajaran kooperatif Tipe Numbered Heads Together (NHT) di kelas VI SDN 1 Koroha Kabupaten Kolaka Utara?. Tujuan penelitian adalah untuk meningkatkan hasil belajar IPS pada materi sistem administrasi wilayah Indonesia siswa melalui penerapan model pembelajaran kooperatif Tipe Numbered Head Together (NHT) di kelas VI SDN 1 Koroha Kabupaten Kolaka Utara. Penelitian ini diharapkan dapat memberikan manfaat bagi guru, siswa, sekolah dan penelitian lainnya.

\section{Metode}

Jenis penelitian adalah penelitian tindakan kelas. Penelitian tindakan kelas adalah penelitian yang dilakukan oleh guru di dalam kelasnya sendiri melalui refleksi diri, dengan tujuan untuk memperbaiki kinerjanya sebagai guru yang profesional, sehingga hasil belajar siswa menjadi meningkat (Aqib, 2007:3). Penelitian ini dilaksanakan pada semester ganjil tahun ajaran 2016/2017 pada siswa kelas VI SD Negeri 1 Koroha Kabupaten Kolaka Utara. Subyek penelitian ini adalah siswa dan guru kelas VI semester ganjil SD Negeri 1 Koroha yang terdaftar pada tahun ajaran 2016/2017, berjumlah 25 orang. Faktor yang diteliti dalam penelitian ini adalah 1) faktor siswa, 2) Faktor guru dan faktor 3) hasil belajar. Penelitian Tindakan Kelas ini dilaksanakan dalam 2 (dua) siklus. Adapun prosedur penelitian tindakan ini meliputi: (1) Perencanaan, (2) Pelaksanaan Tindakan, (3) Observasi dan Evaluasi, dan (4) Refleksi dalam setiap siklus. Jenis data yaitu data kualitatif dan data kuantitatif. Data kualitatif diperoleh melalui observasi, menggunakan lembar observasi sedangkan data kuantitatif diperoleh melalui tes setiap akhir siklus tindakan

Data yang diperoleh dalam penelitian ini dianalisis dengan menggunakan statistik deskriptif yang dimaksudkan untuk memberikan gambaran distribusi hasil belajar siswa yang diajar dengan menggunakan model pembelajaran kooperatif tipe TPS. Indikator keberhasilan penelitian ini adalah 1) Proses pembelajaran dikatakan berhasil jika persentase keberhasilan aktivitas mengajar guru dan persentase aktivitas belajar siswa mencapai $80 \%$ pembelajaran terlaksana sesuai dengan RPP, 2) Ketuntasan hasil belajar siswa tercapai jika minimal $80 \%$ siswa memperoleh nilai minimal 70.

\section{Hasil}

\section{Hasil Belajar Siswa}

Dari segi hasil yaitu hasil belajar siswa, rata-rata hasil belajar siswa pada siklus I sebesar 73 dengan ketuntasan klasikal sebesar 72\% meningkat pada siklus II menjadi 81,2 dengan persentase ketuntasan klasikal sebesar $92 \%$.

2. Aktivitas Mengajar Guru

Aktivitas guru pada siklus I pertemuan pertama sebesar $62,5 \%$ dan pada pertemuan kedua sebesar $75 \%$, meningkat pada siklus II pertemuan pertama menjadi $87,5 \%$ dan pertemuan kedua $100 \%$. 


\section{Aktivitas Belajar Siswa}

Aktivitas siswa pada siklus I pertemuan pertama sebesar $62,5 \%$ dan pada pertemuan kedua sebesar $75 \%$, meningkat pada siklus II pertemuan pertama menjadi $87,5 \%$ dan pertemuan kedua $100 \%$.

\section{Pembahasan}

Tahapan perencanaan sebagai langkah awal dalam PTK, dilaksanakan dengan menyusun skenario pembelajaran, menyiapkan alat dan bahan pembelajaran yang sesuai dengan materi pelajaran, menyiapkan lembar kerja siswa (LKS), menyiapkan lembar observasi guru, menyiapkan lembar observasi siswa dan menyiapkan instrument penelitian.

Pelaksanaan tindakan sebagai bentuk pelaksanaan kegiatan pembelajaran, seperti yang tercantum dalam desain RPP siklus I dan siklus II dilakukan dengan tiga bentuk kegiatan diantaranya adalah kegiatan awal, kegiatan inti dan kegiatan penutup. Kegiatan pembelajaran diawali dengan memberikan apersepsi agar siswa memiliki gambaran pengetahuan yang diperolehnya dan menyampaikan tujuan pembelajaran yang akan dicapai. Pada kegiatan inti, guru mengorganisasikan siswa dalam 7 kelompok, kemudian memberikan masalah dalam bentuk LKS untuk diselesaikan sesuai dengan hasil eksperimen yang dilakukan masingmasing ketua kelompok, dan setelah itu tiap kelompok mempersentasekan hasil pekerjaan kelompoknya. Di akhir pembelajaran, guru memberikan evaluasi untuk mengetahui hasil belajar siswa telah mengikuti proses pembelajaran.

Tahap selanjutnya adalah observasi. Kegiatan yang di observasi dalam kegiatan ini adalah aktivitas guru dan siswa siklus I dan siklus II dengan menerapkan model pembelajaran kooperatif tipe NHT. Untuk aktivitas guru dalam proses pembelajaran pada siklus I, setelah dilakukan analisis diperoleh hasil persentase mencapai $75 \%$, dan aktivitas pelaksanaan pada siklus II mencapai 75\%. Berdasarkan hasil analisis diatas, menunjukkan bahwa aktifitas guru dalam pembelajaran siklus II mengalami peningkatan dibandingkan dengan aktivitas guru pada siklus I.

Berdasarkan hasil observasi pada siklus I guru dan siswa telah melakukan sebagian kegiatan pembelajaran dengan baik. Namun demikian masih terdapat kekurangan-kekurangan yang perlu diperbaiki antara lain: sebagian siswa masih kurang memperhatikan penjelasan guru, siswa masih kurang aktif dalam kelompoknya baik dalam belajar maupun menyelesaikan soal-soal dan siswa belum berani menyampaikan pendapat, bertanya maupun mengambil hasil pekerjaan temannya. Sedangkan kelemahan dan kekurangan yang dialami guru adalah antara lain: pada pertemuan pertama guru kurang memotivasi siswa dalam belajar ataupun diskusi, dan guru juga belum dapat mengelola waktu dengan baik. Sehingga berdampak pada hasil belajar siswa. Dimana hanya 18 atau $72 \%$ siswa yang mencapai KKM dengan rata-rata 73. Selain itu juga hasil belajar yang diharapkan belum mencapai indikator keberhasilan atau belum mencapai $80 \%$ siswa yang mendapat 70, maka guru melanjutkan pada tindakan siklus II.

Selanjutnya pada siklus II dengan tetap menggunakan model pembelajaran kooperatif tipe NHT, pada materi pelajaran sistem administrasi wilayah Indonesia dimana menunjukkan aktivitas guru dalam proses pembelajaran sudah meningkat dimana kekurangan-kekurangan pada siklus I sudah dapat diperbaiki dengan baik sehingga tersebut membuat hasil belajar siswa menjadi meningkat. Hal ini terlihat pada siklus belajar yang dicapai 23 atau 92\% siswa yang mencapai KKM dengan nilai rata-rata 81,2. Dengan demikian hipotesis penelitian ini telah tercapai. 


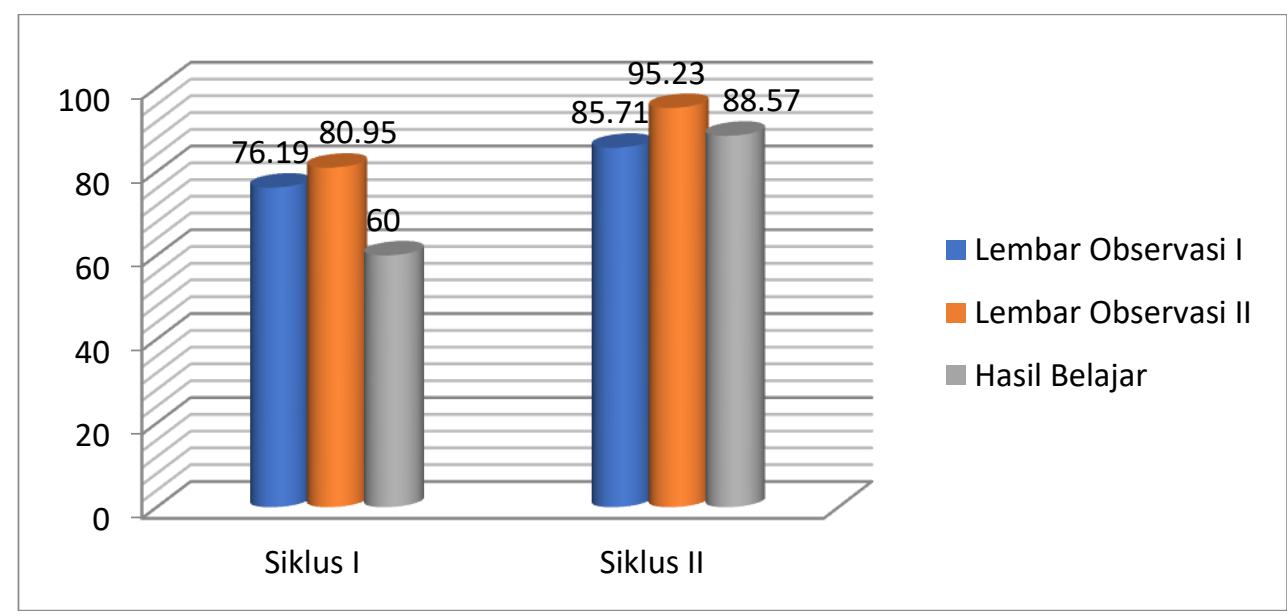

Grafik 1. Hasil Analisis Aktivitas Guru dan Siswa Serta Hasil Belajar

Berdasarkan garfik di atas menunjukan bahwa peningkatan hasil belajar siswa serta aktivitas guru dan siswa dengan menerapkan model pembelajaran kooperatif tipe NHT dari tiap siklus meningkat. Peningkatan aktivitas guru dan siswa ini karena semakin terbiasa menggunakan model pembelajaran kooperatif tipe NHT sehingga tiap pertemuan itu pembelajaran semakin efektif dan bermakna sehingga membawakan hasil yang sangat memuaskan. Dengan pernyataan tersebut maka akan merubah hasil blajar siswa di mana pada model pembelajaran kooperatif ini siswa dituntut untuk saling bekerja sama, bertukar pikiran. Menuru Ibrahim (dalam Trianto, 2009:6) model pembelajaran kooperatif tipe NHT merupakan kegiatan pembelajaran yang menciptakan suasana siswa merasa ambil bagian dan berperan aktif dalam proses kegiatan pembelajaran, lebih rileks di samping menumbuhkan tanggung jawab, kerjasama, persaingan sehat dan keterlibatan belajar. Salah satu yang ditempuh guru adalah mengembangkan pola pembelajaran menekankan kerjasama antar siswa dalam membentuk individu siswa menjadi manusia yang demokratis. Model pembelajaran kooperatif Tipe NHT ini, pada hakikatnya dirancang untuk memberikan kesempatan pada siswa dapat belajar melalui kegiatan bermain, berlomba dan bekerjasama dalam tim. Keberhasilan dari penerapan pembelajaran kooperatif tipe NHT ini bergantung kepada peran dan kesiapan guru di dalamnya. Peran guru tersebut sangat tergantung dari kegiatan pembelajaran yang digunakan, juga materi yang sedang diajarkannya.

\section{Simpulan}

1. Persentase kualitas pelaksanaan pembelajaran yang dilaksanakan guru mengalami peningkatan dalam penerapan model pembelajaran kooperatif tipe NHT dilihat pada persentase yang diperoleh setiap siklunya yaitu siklus I pertemuan pertama $62,5 \%$ dan pertemuan kedua $75 \%$ sedangkan pada siklus II meningkat menjadi $87,5 \%$ untuk pertemuan pertama dan $100 \%$ untuk pertemuan kedua.

2. Aktivitas siswa selama kegiatan pembelajaran siklus I pada materi sistem perkembangan wilayah Indonesia dengan penerapan model pembelajaran kooperatif tipe NHT mengalami peningkatan yaitu pada siklus I pertemuan pertama $762,5 \%$ dan pertemuan kedua $75 \%$ sedangkan pada siklus II meningkat menjadi $87,5 \%$ untuk pertemuan pertama dan $100 \%$ untuk pertemuan kedua.

3. Kemampuan belajar siswa pada materi sistem perkembangan pemerintahan wilayah Indonesia dengan penerapan model pembelajaran kooperatif tipe NHT, berdasarkan tes hasil belajar siswa meningkat dengan persentase ketuntasan secara klasikal pada siklus I yaitu $72 \%$ dan pada siklus II yaitu $92 \%$. 


\section{Referensi}

Aqib, Zainal, 2007. Penelitian Tindakan Kelas. Bandung: Yrama Widya

Istiana, 2012. Upaya Meningkatkan Hasil Belajar IPS Melalui Model Pembelajaran Kooperatif Tipe Numbered Head Together (NHT) pada Siswa Kelas IV SD Negeri 2 Lawoila Kabupaten Konawe Selatan. Kendari: Universitas Haluoleo

Nursyamsi, dkk. 2016. Pengaruh Strategi Pembelajaran Nurbered Heads Together (NHT) Terhadap Hasil Belajar Siswa SMA Negeri 1 Muara Barak. Jurnal Pendidikan: Teori, Penelitian dan Pengembangan Vol.1 No. 10 Hal. 1993-1998.

Salim, 2012. Meningkatkan Hasil Belajar IPS Melalui Model Pembelajaran Kooperatif Tipe Numbered Head Together (NHT) pada Siswa Kelas IV SD Negeri 13 Poasia. Kendari: Universitas Haluoleo

Sudjana, N., 2002. Penilaian dan Proses Belajar Mengajar. Bandung: Remaja Rosdakarya

Trianto, 2010. Model-Model Pembelajaran Inovatif Berorientasi Kontruktivistik. Jakarta: Prestasi Pustaka

Usman, U., 2001. Menjadi Guru Profesional. Bandung: Remaja Rosdakarya 